\title{
Sosialisasi Hidup Sehat Sejak Dinitentang Makanan Olahan Di SD Manjushri Padang 2020
}

\author{
Reny Salim \\ Akademi Farmasi Prayoga \\ Email: renysalim@akfarprayoga.ac.id
}

\begin{abstract}
Abstrak
Kebutuhan energi manusia berasal dari makanan yang dikonsumsinya. Jenis makanan di zaman teknologi ini sangat banyak sehingga manusia harus mempunyai kemampuan untuk menyikapinya. Salah satu jenis makanan yang berdampak negatif pada kesehatan tubuh manusia adalah junk food. Junk food sangat berbahaya jika dikonsumsi dalam jumlah berlebihan. Kemampuan manusia mengonsumsi junk food secara berlebih karena adanya zat yang dapat mengaktifkan rasa candu didalam naluri manusia. Adanya masalah ini dalam masyarakat menimbulkan sikap melakukan pembinaan melalui kegiatan sosialisasi hidup sehat sejak dini tentang makanan olahan yang bertujuan meningkatkan pola hidup sehat masyarakat. Sosialisasi ini diberikan pada siswa kelas V SD Manjushri pada hari Kamis, 06 Februari 2020 selama \pm 1 jam. Hasil kegiatan memberikan informasi bahwa secara umum masyarakat sudah mengetahui dampak buruk mengonsumsi junk food namun belum mengetahui dengan sangat jelas dampak jangka pendek dan jangka panjang dari mengonsumsi junk food secara berlebihan.
\end{abstract}

Kata kunci: hidup sehat, junk food

\begin{abstract}
Human energy needs come from the food they consume. There are so many types of food in this technological age that humans must have the ability to react to them. One type of food that has a negative impact on the health of the human body is junk food. Junk food is very dangerous if consumed in excessive amounts. The ability of humans to consume excess junk food is due to substances that can activate taste in human instincts. The existence of this problem in society has led to an attitude of providing guidance through socialization of healthy living from an early age on processed food which aims to improve the healthy lifestyle of the community. This socialization was given to grade V SD Manjushri students on Thursday, February 6,2020 for \pm 1 hour. The results of the activity provide information that in general, we have seen the bad effects of consuming junk food but have not clearly seen the short-term and long-term impacts of consuming excessively junk food.
\end{abstract}

Keyword: healthy life, junk food

\section{PENDAHULUAN}

Makanan adalah sumber energi utama manusia. Makanan yang dikonsumsi manusia berasal dari alam dapat langsung dikonsumsi ataupun diolah terlebih dahulu. Proses pengolahan itu ada yang praktis ataupun kompleks. Pengolahan praktis yang dimaksud ini adalah pengolahan dengan cara alami menggunakan bahan-bahan alam yang tidak mengalami

http://ejournal.urindo.ac.id/index.php/PAMAS

Article History : 
pengolahan terlebih dahulu. Pengolahan kompleks adalah pengolahan yang menggunakan bahan hasil olahan dari pabrik, maksudnya menggunakan bumbu-bumbu yang dikenal dengan nama aditif makanan atau bahan tambahan makanan [1].

Bahan tambahan makanan adalah bahan yang ditambahkan secara sengaja ke dalam makanan dalam jumlah kecil. Keberadaan bahan ini pada makanan dimaksudkan untuk meningkatkan nilai gizi, memperbaiki penampakan, cita rasa, tekstur, dan memperpanjang daya simpan. Secara alami keberadaan zat aditif ini tidak menimbulkan efek yang merugikan bagi manusia. Namun setelah dikonsumsi dalam jumlah dan waktu yang lama memperlihatkan efek yang merugikan manusia yaitu menyebabkan sebuah penyakit, mengganggu atau merusak fungsi organ, menyebabkan kecanduan. [2]

Jenis makanan olahan yang disukai oleh masyarakat adalah fast food tepatnya junk food. Hal ini disebabkan oleh rasanya yang gurih, bentuknya yang menarik, tersedia secara luas, dan harganya yang terjangkau [3]. Menurut hasil survei tahun 2008 yang dilakukan oleh Nilsen, didapatkan data bahwa 69\% masyarakat kota di Indonesia mengonsumsi fast food dengan alasan: $33 \%$ sebagai makan siang, $25 \%$ makan malam, $9 \%$ makanan selingan, dan $2 \%$ memilih untuk makan pagi. [4] Namun setelah dilakukan penelitian mengonsumsi makanan olahan jenis junk food dalam waktu yang sering dan tanpa diimbangi dengan olahraga, konsumsi serat dan mineral dari buah dan sayuran menimbulkan efek yang merugikan bagi manusia [5].

Dampak yang teramati bagi anak, remaja, dan dewasa yang mengonsumsi junk food berlebihan adalah obesitas. Jika seseorang memiliki kelebihan berat badan (obesitas) yang sangat signifikan maka dapat diasumsikan menderita penyakit degeneratif seperti jantung, diabetes dan tekanan darah tinggi.[6] Penyebab obesitas adalah tingginya kadar kalori seperti tinggi lemak (lemak jenuh, lemak trans, kolesterol), gula aditif, garam, dan penyedap, namun sedikit nutrisi [7].

Peningkatan kadar kalori dalam makanan yang dikonsumsi menyebabkan obesitas. Hal ini diketahui berdasarkan hasil penelitian yang dilakukan di Bangladesh terhadap siswa yang mengonsumsi makanan junk food $\geq 2$ kali seminggu dapat mengalami obesitas. Di Indonesia, menurut hasil riset kesehatan dasar 2015 prevalensi obesitas anak yang dihitung berdasarkan indeks massa tubuh dibandingkan usia pada kelompok anak usia 5-12 tahun besarnya 8\%. Menurut perkiraan angka tersebut akan mencapai 9,1\% atau 60 juta di tahun 2020 karena perubahan gaya hidup. Perubahan gaya hidup dari tradisional life style menjadi sedentary life style yaitu gaya kehidupan dengan aktivitas fisik sangat kurang.[8]. 
Aktivitas fisik yang dilakukan dalam bentuk bermain game, menonton televisi hanya membutuhkan sedikit energi jika dibandingkan dengan bermain kejar-kejaran, petak umpet, atau tarik tambang. Aktivitas fisik berkaitan dengan kalori yang terdapat dalam tubuh. Jika aktivitas tubuh kurang dibandingkan kalori yang ada maka kalori akan disimpan oleh tubuh dalam bentuk lemak pada rongga perut, panggul, ataupun lengan [9].

Jika pengetahuan dan data ini tidak disosialisasikan secara berulang-ulang kepada masyarakat dapat berakibat meningkatnya persentase obesitas pada anak, remaja, dan dewasa. Obesitas berefek pada penyakit degeneratif yang merugikan kondisi keuangan dan tubuh akibat ketergantungan pada obat [9]. Salah satu cara untuk mengurangi persentase obesitas adalah pemberian pengetahuan lewat sosialisasi hidup sehat kepada anak atau orang tua secara berulang dan dini.

\section{A. Nama kegiatan}

Kegiatan pengabdian masyarakat ini diberi nama : "Sosialisasi hidup sehat sejak dini tentang makanan olahan"

B. Maksud dan tujuan

a. memberikan pemahaman sejak dini tentang jenis-jenis makanan olahan (fast food dan junk food).

b. memberikan pemahaman sejak dini tentang dampak jenis makanan olahan (junk food).

c. memperbaiki pola makan anak sejak usia dini.

d. meningkatkan pola hidup masyarakat sehat.

\section{PELAKSANAAN KEGIATAN}

Kegiatan sosialisasi hidup sehat sejak dini tentang makanan olahan dilaksanakan pada:

$\begin{array}{ll}\text { Hari/Tanggal } & : \text { Kamis/06 Februari } 2020 \\ \text { Waktu } & : \text { 08.15-09.20 WIB } \\ \text { Tempat } & : \text { SD Manjushri Padang }\end{array}$

\section{PARTISIPAN}

Kegiatan pengabdian ini diikuti oleh siswa kelas V SD sebanyak 14 orang, 1 orang guru SD, dan 2 orang mahasiswa AKFAR Prayoga. 


\section{METODE KEGIATAN}

Kegiatan pengabdian masyarakat "Sosialisasi Hidup Sehat Sejak Dini: Makanan Olahan" dilakukan dengan 3 tahapan yang disajikan pada tabel 1. Tiap tahapan dibuat semenarik mungkin menggunakan metode tanya jawab dan ajakan. Kegiatan inti disajikan pada slide yang dibuat menggunakan Microsoft power point. Bahan yang disajikan pada slide dipaparkan pada tabel 2.

Tabel 1. Jenis Kegiatan Selama Sosialisasi

\begin{tabular}{ll}
\hline Tahapan & Jenis Kegiatan \\
\hline Pembukaan & Pengenalan Narasumber dan Kampus Asal Narasumber \\
& Identifikasi Contoh Makanan Cepat Saji Kegemaran Peserta \\
& Identifikasi Pemahaman Peserta tentang Makanan Sehat \\
& Penyampaian Konsep Makanan Sehat \\
& Pengenalan Istilah Fast Food dengan Junk Food \\
& Pembedaan Jenis Makanan Fast Food dengan Junk Food \\
Inti & Penyampaian Fakta dan Dampak Junk Food \\
& Penyampaian Penyebab Ketagihan Junk Food \\
& Penyampaian Solusi Pengurangan Dampak Junk Food \\
& Ajakan Konsumsi Makanan Sehat \\
& Kuis (3 pertanyaan tentang materi yang dipaparkan) \\
& Ajakan Hidup Sehat \\
Penutup & Foto Bersama Peserta
\end{tabular}

Tabel 2. Materi Sosialisasi Hidup Sehat Sejak Dini “ Makanan Olahan”

\begin{tabular}{ll}
\hline Nomor Slide & Isi Slide \\
\hline 1 & Gambar dari Contoh Makanan Cepat Saji \\
2 & Video Perbedaan Fast Food dan Junk Food \\
3 & Video Fakta Junk Food \\
4 & Video Dampak Junk Food \\
5 & Video Penyebab Ketagihan Makanan Cepat Saji \\
6 & Point-point Solusi Pengurangan Dampak Junk Food \\
7 & Video Lagu “Good Food dan Ayo Hidup Sehat”. \\
\hline
\end{tabular}




\section{TARGET LUARAN}

Luaran yang ditargetkan dari kegiatan pengabdian masyarakat ini adalah pemahaman dan pengaplikasian pola hidup sehat sejak dini oleh peserta.

\section{HASIL KEGIATAN}

Kegiatan sosialisasi ini berlangsung selama \pm 1 jam dengan suasana ramah dan akrab. Kondisi ini menimbulkan sikap ketertarikan dari peserta terhadap materi yang disajikan. Peserta yang ikut sosialisasi ini merupakan siswa SD yang secara keseluruhan dari mereka menyukai makanan jenis fast food seperti junk food. Selama kegiatan ada peserta (siswa) yang menyatakan bahwa dia mengetahui junk food berbahaya bagi kesehatan namun tidak mengetahui secara jelas bahaya atau dampak mengonsumsi junk food secara berlebihan. Peserta tersebut merasa sangat bahagia dengan adanya sosialisasi ini sehingga memberikan kejelasan pengetahuan yang dimilikinya. Peserta lain menanyakan kepada narasumber berkenaan dengan hubungan antara junk food terhadap perasaan depresi. Narasumber menjelaskan bahwa pada saat stress kadar kortikoson meningkat signifikan dalam tubuh. Peningkatan ini memicu sistim informasi saraf ke otak untuk mengonsumsi makanan yang tinggi lemak atau manis. Kondisi stress yang berlangsung lama jika diatasi dengan terus mengonsumsi junk food mengakibatkan terganggunya sistim kesehatan organ tubuh lainnya. Narasumber menyarankan kepada peserta agar mengontrol rasa stress dengan cara lain demi hidup sehat.

Kegiatan sosialisasi ini harus berakhir karena keterbatasan waktu yang diberikan kepada narasumber. Narasumber menyadari bahwa pertanyaan yang diajukan memperlihatkan sikap ketertarikan yang sangat tinggi namun keterbatasan waktu dan kemampuan dasar dari peserta dalam menyusun pertanyaan dan pemahaman konsep metabolisme tubuh menimbulkan kesulitan narasumber dalam memberikan kepuasan pemahaman kepada peserta. Hal ini menjadi evaluasi bagi narasumber untuk menyederhanakan penjelasan materi sosialisasi yang disajikan kepada peserta.

\section{SIMPULAN}

Berdasarkan kegiatan pengabdian yang dilakukan terlihat bahwa masyarakat (khususnya anak sekolah dasar) sudah mengetahui dari orang tuanya bahwa makanan olahan jenis junk food tidak boleh dikonsumsi karena dapat membahayakan kesehatan. Namun mereka belum 
Jurnal Pelayanan dan Pengabdian Masyarakat (PAMAS)

mengetahui dengan pasti dampaknya dan tidak mengetahui dampak makanan olahan tersebut serta gejala dalam waktu dekat yang dapat dikenali dari mengonsumsi makanan olahan jenis junk food ini.

\section{DOKUMENTASI KEGIATAN}
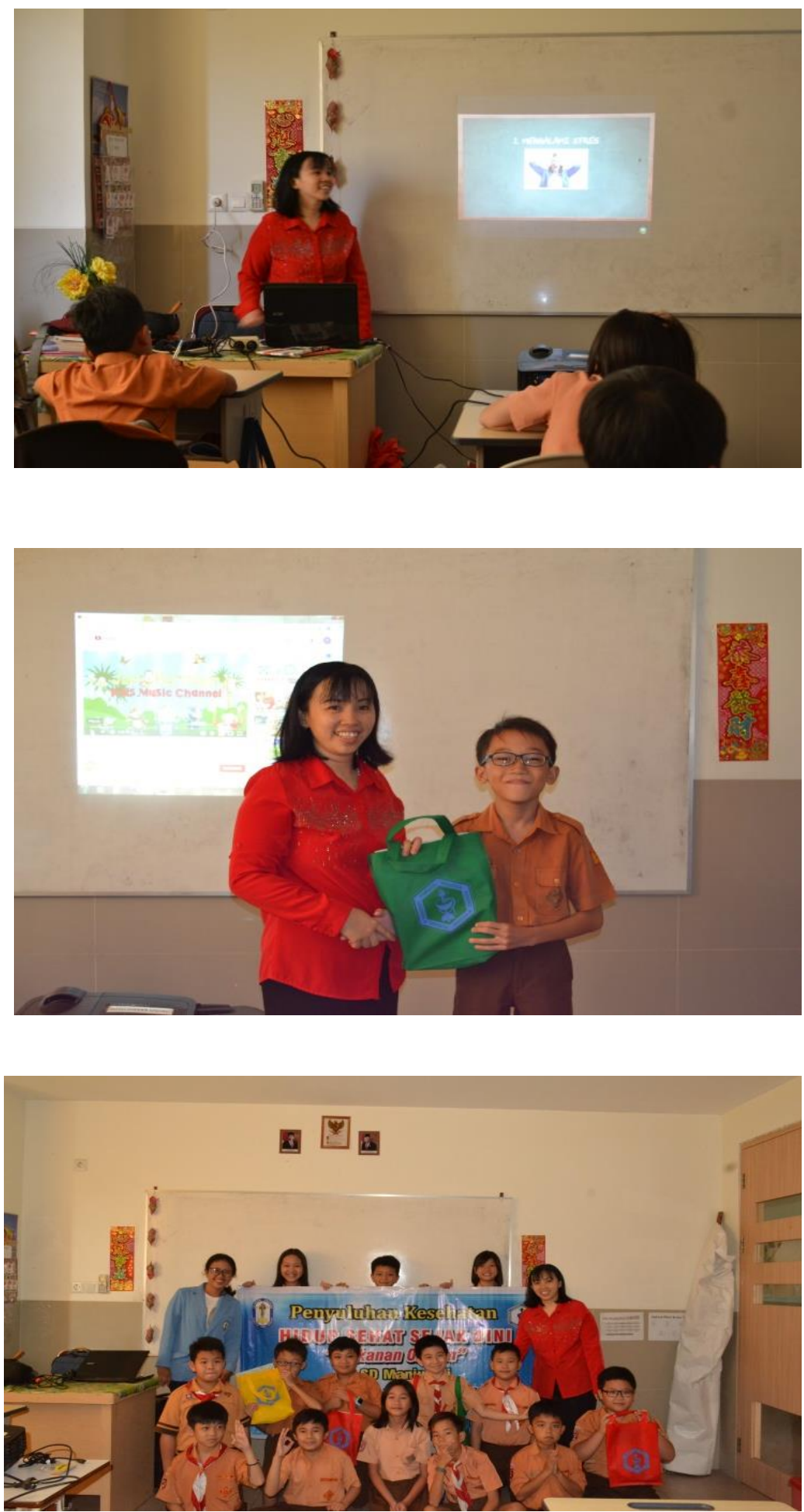


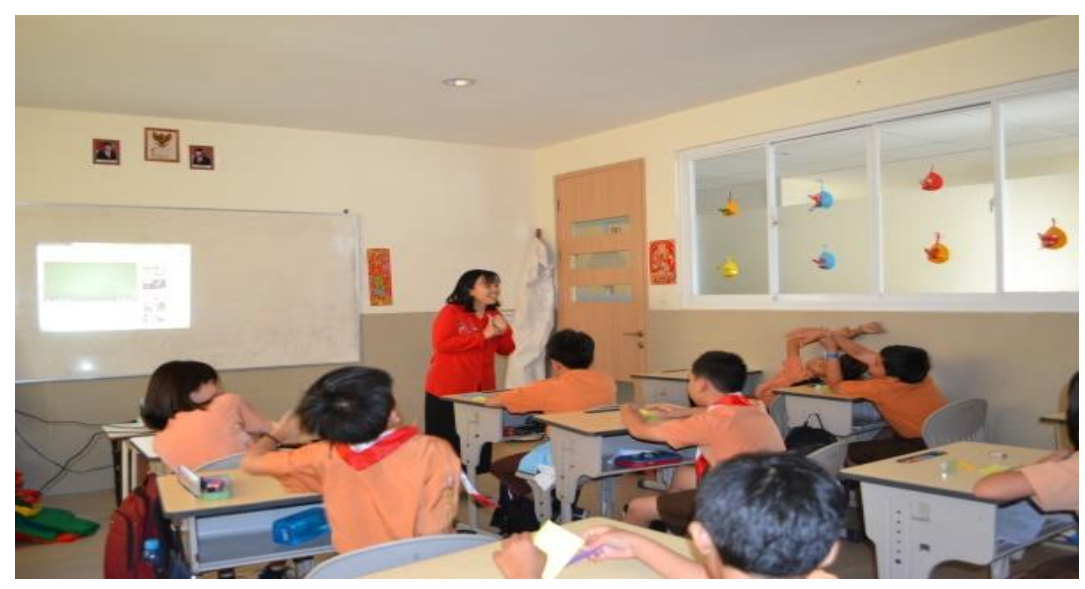

\section{REFERENSI}

Sempati, G. P.H.,\& Badraningsih L. Persepsi dan Perilaku Remaja Terhadap Makanan Tradisional dan Makanan Modren. 2017 p. 1-9.

Armansyah, V.A. 2019. Zat Aditif. diunduh pada tanggal 16 Januari 2020. https://rumus.co.id/zat-aditif/.

Sari, E. 2019. Beberapa Alasan Orang Menyukai Junk Food. diunduh pada tanggal 23 Januari 2020. https://5news.co.id/artikel/2019

Hanum TSL, Dewi AP, Erwin. Hubungan Antara Pengetahuan dan Kebiasaan Mengkonsumsi Fast Food dengan Status Gizi Pada Remaja. J Online Mhs. 2009; 2(1):750-8.

Pamelia I. Perilaku Konsumsi Makanan Cepat Saji Pada Remaja Dan Dampaknya Bagi Kesehatan. Ikesma. 2018;14(2):144.

Cahaya, A. 2018. Perilaku Remaja tentang Konsumsi Makanan Cepat Saji (Fast Food) di SMK Muhammadiyah 9 Medan. diunduh pada 16 Januari 2020.

Adrian, K. 2019. Ini Bahaya Makanan Siap Saji yang Bisa Mengintai Anda. diunduh pada tanggal 18 Januari 2020. https://www.alodokter.com/ini-bahaya-makanan-siap-sajiyang-bisa-mengintai-anda

Jannah M, Utami TN. Faktor yang Memengaruhi Terjadinya Obesitas Pada Anak Sekolah di SDN 1 Sigli Kabupaten Pidie. J Kesehat Glob. 2018;1(3):110.

Izhar MD. Hubungan Antara Konsumsi Junk Food, Aktivitas Fisik Dengan Status Gizi Siswa Sma Negeri 1 Jambi. Open Sci Framew. 2019;(May):0-5. 